\title{
RANCANGAN APLIKASI GUDANG PADA PT. HOLLAND BAKERY
}

\author{
Serniawan Dwi Nugroho ${ }^{1}$, Puji Astuti ${ }^{2}$, Mahyudi $^{3}$ \\ ${ }^{1,2,3}$ Teknik Informatika, Fakultas Teknik dan Ilmu Komputer, Universitas Indraprasta PGRI Jakarta \\ Jalan Raya Tengah No 80, Kelurahan Gedong, Pasar Rebo, Jakarta Timur \\ 1.
}

\begin{abstract}
ABSTRAK
Permasalahan yang dihadapi oleh PT. Holland Bakery terfokus pada belum adanya sistem informasi dalam pengelolaan barang masuk dan barang keluar pada gudang PT. Holland Bakery kemudian pencarian data barang masuk dan barang keluar pada gudang PT. Holland Bakery masih memerlukan waktu yang cukup lama. Tujuan merancang suatu sistem aplikasi gudang ini dengan tujuan untuk memudahkan admin dan bagian gudang dalam memproses pengolahan data yang ada saat ini hingga sampai ke pelaporannya. Perangkat aplikasi yang telah dibuat dengan bahasa pemrograman Java NetBeans 8.0.2 dan penyimpanan data pada database MySQL dapat memberikan kelancaran dalam proses menginput dan penyimpanan data-data serta laporan-laporan yang diberikan kepada pimpinan perusahaan. Dengan menggunakan metode pengembangan sistem yaitu Waterfall dalam penelitian ini adalah dengan tahapan-tahapan seperti rekayasa sistem, analisis, desain, coding, testing, dan maintenance. Hasil dari penelitian ini menciptakan suatu sistem informasi untuk memudahkan karyawan dalam pencarian data barang masuk dan barang keluar pada gudang PT. Holland Bakery serta menghasilkan laporan data barang masuk dan barang keluar pada gudang PT. Holland Bakery yang cepat dan akurat.
\end{abstract}

Kata Kunci: Aplikasi, Gudang, Desktop

\section{ABSTRACT}

The problems faced by PT. Holland Bakery focuses on the absence of an information system in the management of incoming and outgoing goods at the PT. Holland Bakery then searches data for incoming and outgoing goods at the PT. Holland Bakery still takes a long time. The purpose of designing a warehouse application system is to make it easier for admins and the warehouse department to process the current data processing up to reporting. Application tools that have been created using the Java NetBeans 8.0.2 programming language and data storage in the MYSQL database can provide smooth processing of input and storage of data and reports provided to company leaders. By using the system development method, namely Waterfall, in this research, the stages are systems engineering, analysis, design, coding, testing, and maintenance. The results of this study created an information system to make it easier for employees to search for incoming and outgoing goods data at the PT. Holland Bakery and produce data reports of incoming and outgoing goods at the PT. Fast and accurate Holland Bakery.

Key Word: Application, Warehouse, Desktop

\section{PENDAHULUAN}

Perkembangan teknologi komputer pada saat ini sudah banyak dibutuhkan penggunaannya karena dapat mempermudah dalam pengaksesan jaringan-jaringan yang dapat dilakukan untuk perpindahan dari sebuah data menjadi informasi. Kemampuan pada teknologi dapat mempermudah untuk mendapatkan data dan informasi secara lebih cepat. Komputer tidak hanya digunakan dalam bidang perbankan, transportasi, pendidikan (Meisak, 2017), tetapi juga dalam bidang industri. Dalam bidang industri, komputer sangat dibutuhkan untuk menginput dan serta pengelolaan barang masuk dan barang keluar pada suatu perusahaan (Agusvianto, 2017).

Holland Bakery sebagai salah satu jaringan toko roti terkemuka di Indonesia dengan 22 cabang (dapur pusat) mengelola lebih dari 400 gerai: Jabodetabek (Gajah Mada, Pondok Pinang, Jatinegara, Cikini, Sunter, Serpong, Ciputat, Pekayon, Bogor dan Karawang), Bandung, Surabaya, Lampung, Batam, Pekanbaru, Makassar, Manado, Bali, Solo, Semarang, Balikpapan dan Samarinda.Perusahaan tersebut 
masih terus berekspansi secara nasional ke kotakota lain. Holland Bakery adalah salah satu pelopor dalam bisnis bakery modern di Indonesia. Didirikan pada tahun 1978, Holland Bakery saat ini dikelola di bawah PT. Mustika Citra Rasa. Produk yang dijual memiliki keunggulan yaitu sehat, bergizi, dan terjangkau oleh semua orang.

PT. Holland Bakery dalam proses barang masuk dan barang keluar di gudang masih bersifat manual dan masih seringnya terjadi human error (Waluyo, Hanafri, \& Sulaeman, 2019). Selain itu untuk menjamin lancarnya arus lintas barang maka perlu diadakan pencatatan terhadap segala penerimaan barang yang berasal dari supplier, barang yang dipesan oleh pelanggan, barang yang terjual, barang yang dikembalikan oleh langganan dan penyesuaian-penyesuaian (adjusment) terhadap barang. Atas dasar pencatatan tersebut nantinya dapat diketahui antara lain barang yang banyak tertimbun (over stock), barang yang harus dipesan kembali kepada supplier karena persediaannya sudah menipis, apabila terjadi pemesanan barang kepada supplier, maka pemesanan ini perlu pula dicatat untuk mendapatkan informasi tentang pengelolaan barang masuk dan barang keluar secara lengkap (Wibowo, Rumagit, \& Tuturoong, 2014).

Dengan permasalahan tersebut, perlu ada nya suatu sistem yang terkomputerisasi dalam penyelesaiannya. Sistem adalah sekelompok unsur yang erat hubungannya satu dengan yang lain, yang berfungsi bersama-sama untuk mencapai tujuan (Sutabri, 2012). Sistem merupakan suatu kumpulan dari komponenkomponen yang membentuk satu kesatuan (Tyoso, 2016). Pembangunan sistem adalah sekumpulan aktivitas yang menggambarkan secara rinci bagaimana sistem akan berjalan. Hal itu bertujuan untuk menghasilkan produk perangkat lunak yang sesuai dengan kebutuhan user (Satzinger, J. W., Jackson, R. B., Burd, n.d.).

Diharapkan dengan adanya suatu sistem informasi dapat menangani permasalahan yang ada di perusahaan tersebut. Sistem adalah setiap sesuatu terdiri dari obyek-obyek, atau unsur-unsur, atau komponen-komponen yang bertata kaitan dan bertata hubungan satu sama lain, sedemikian rupa sehingga unsur-unsur tersebut merupakan satu kesatuan pemrosesan atau pengolahan yang tertentu. (Prasojo, 2011)

Aplikasi ini dapat memudahkan pekerjaan Admin dan Bagian Gudang dalam mengontrol stok barang masuk dan barang keluar pada gudang PT. Holland Bakery dan mempermudah dalam proses pembuatan laporan kepada pimpinan perusahaan.

\section{METODE PENELITIAN}

Peneliti menggunakan metode Grounded Research dalam penyelesaian penelitian ini. (Sugiyono, 2016). Metode penelitian yang dilakukan dengan menggunakan metode grounded research dan metode observasi (pengamatan). Metode grounded research yaitu suatu metode penelitian yang berdasarkan fakta dengan tujuan dapat menetapkan konsep, mengembangkan teori, pengumpulan dan analisis data dalam waktu yang bersamaan. Sedangkan metode observasi (pengamatan) merupakan metode pengumpulan data yang dilakukan secara sistematis dan sengaja melalui pengamatan dan pencatatan serta gejala objek yang diteliti langsung dilapangan, sebab metode observasi merupakan salah satu teknik penelitian yang sangat penting bagi seorang peneliti secara langsung dilapangan. Pengamatan ini dilakukan secara langsung merupakan alat ampuh untuk menguji suatu kebenaran. Dalam mengumpulkan data dan informasi yang diperlukan, dilakukan penelitian secara langsung ke bagian gudang PT. Holland Bakery.Selain itu juga dilakukan klasifikasi terhadap data tersebut, mengolah dan menganalisa data, membangun hipotesis menjadi teori (Putra, 2011).

\section{HASIL DAN PEMBAHASAN Analisa Permasalahan}

Analisis pemasalahan yang dapat diambil dari hasil penelitian yang dilakukan di PT. Holland Bakery Jakarta adalah bahwa, perusahaan ini termasuk salah satu perusahaan yang belum memiliki sistem administrasi pengolahan data gudang berbasis komputerisasi, sehingga dirasakan masih sangat membutuhkan sistem yang mampu dan memberikan kemudahan bagi bagianbagian yang terkait dalam sistem aplikasi gudang. Ada beberapa permasalahan yang dimiliki oleh pihak perusahaan antara lain, laporan pesanan 
yang masih dilakukan pencatatan secara manual dengan menggunakan berkas sehingga menyulitkan petugas ketika akan melakukan pencarian data ataupun pengarsipan data. Pencatatan data permintaan dan pesanan yang berjalan belum maksimal karena penggunaan berkas sebagai sarana pencatatan pesanan. Dalam proses pengarsipan permintaan dan pesanan perusahaan masih menggunakan pencatatan buku besar sehingga petugas sering kesulitan mencari data satu persatu.

\section{Alternatif Penyelesaian Masalah}

Alternatif penyelesaian masalah yang diusulkan adalah dengan membuat sebuah sistem aplikasi gudang dengan menggunakan bahasa pemrograman Java dan penyimpanan data-data pada media database. Dengan adanya aplikasi ini diharapkan mampu memberikan kontribusi yang positif bagi kemajuan dalam pengolahan data-data barang masuk dan barang keluar. Proses pencarian data tidak lagi membutuhkan waktu yang lama karena data-data perusahaan yang ada sudah tersimpan pada media database. Dengan usulan ini diharapkan permasalahan pada pengolahan data-data barang masuk dan barang keluar perusahaan dapat tertangani dengan cepat dan akurat.

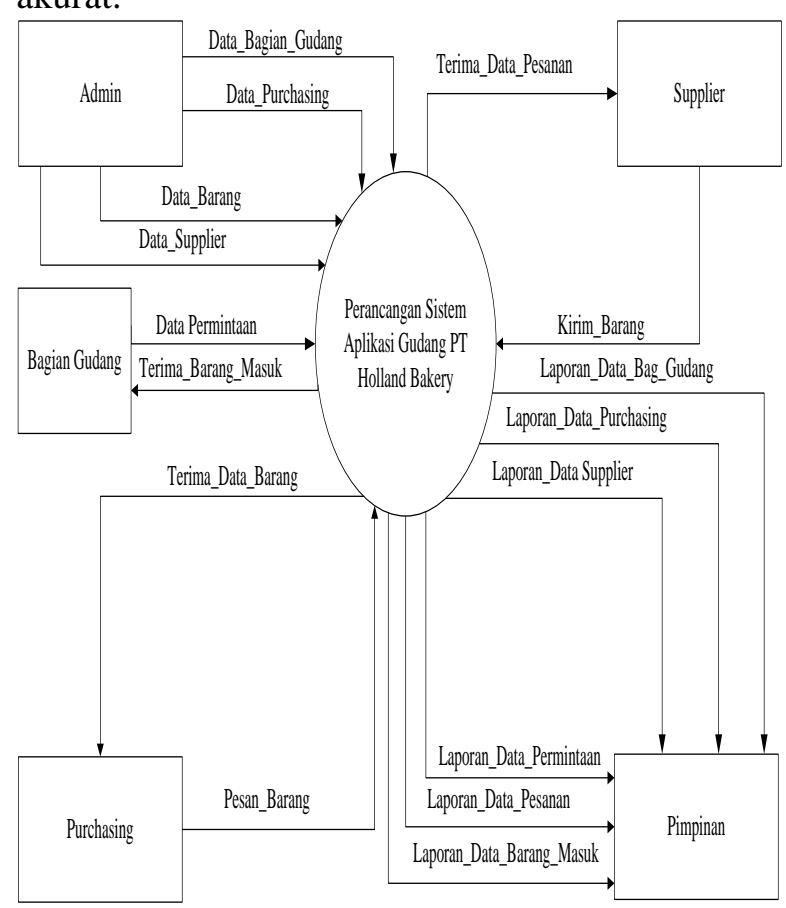

Gambar 1. Diagram Konteks

575 | Rancangan Aplikasi Gudang pada PT. Holland Bakery

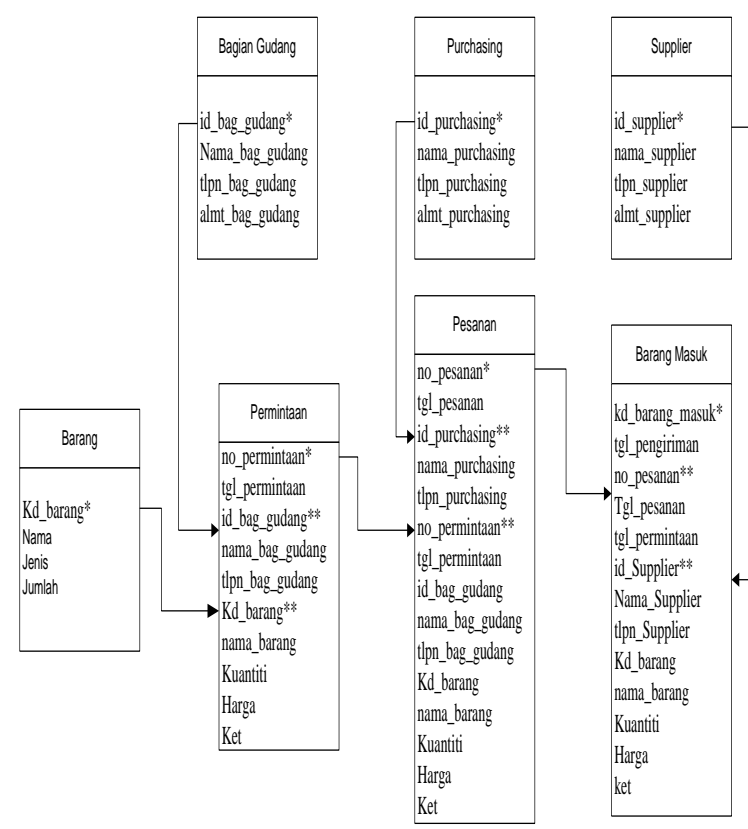

Gambar 2. Normalisasi

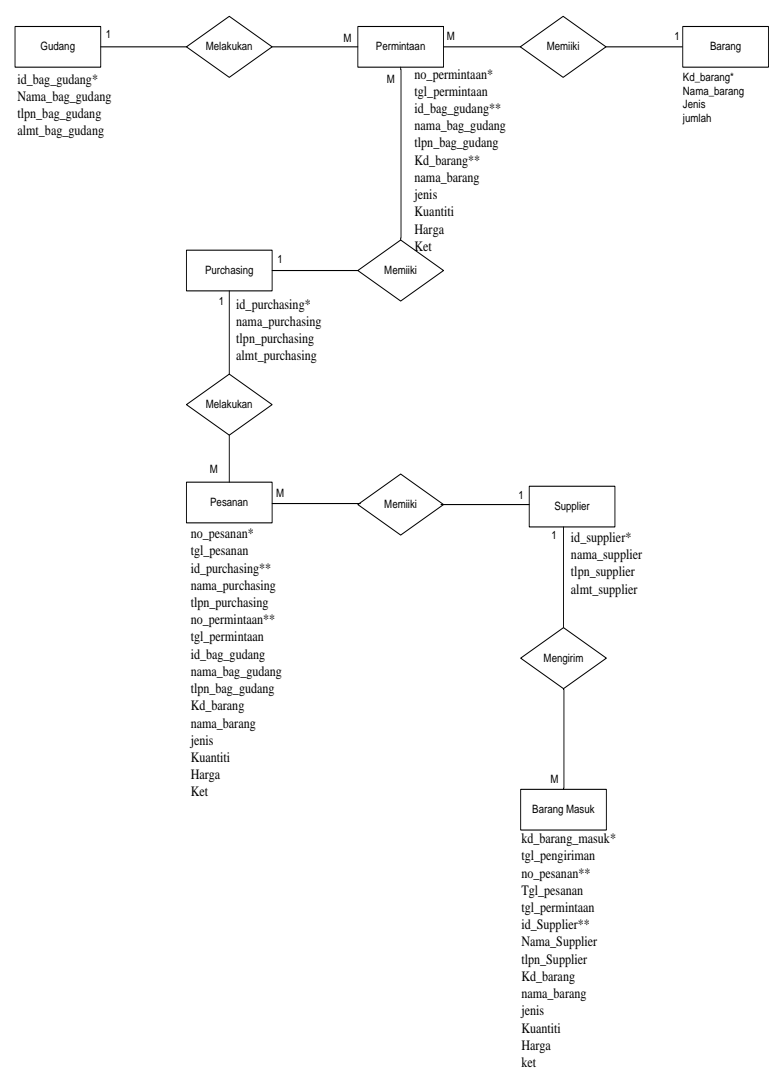

Gambar 3. ERD (Entity Relationship Diagram)

Berikut adalah tampilan layar dan hasil pengujian pada software program yang telah di buat dengan bahasa pemrograman Java. 
aition

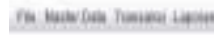

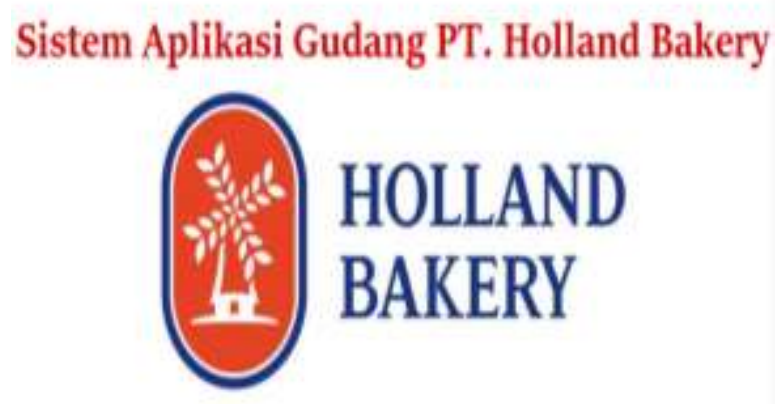

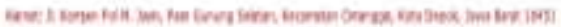

\section{Gambar 3. Form Menu Utama}

Layar di atas menampilkan tampilan Menu Utama pada Sistem Aplikasi Gudang PT. Holland Bakery. Pada layar utama tersedia menu bar yang terdiri dari master data yang digunakan untuk memasukkan data yang berkaitan dengan data barang, data gudang, data supplier, data permintaan, data pesanan, data barang masuk, data barang keluar dan laporan-laporan.

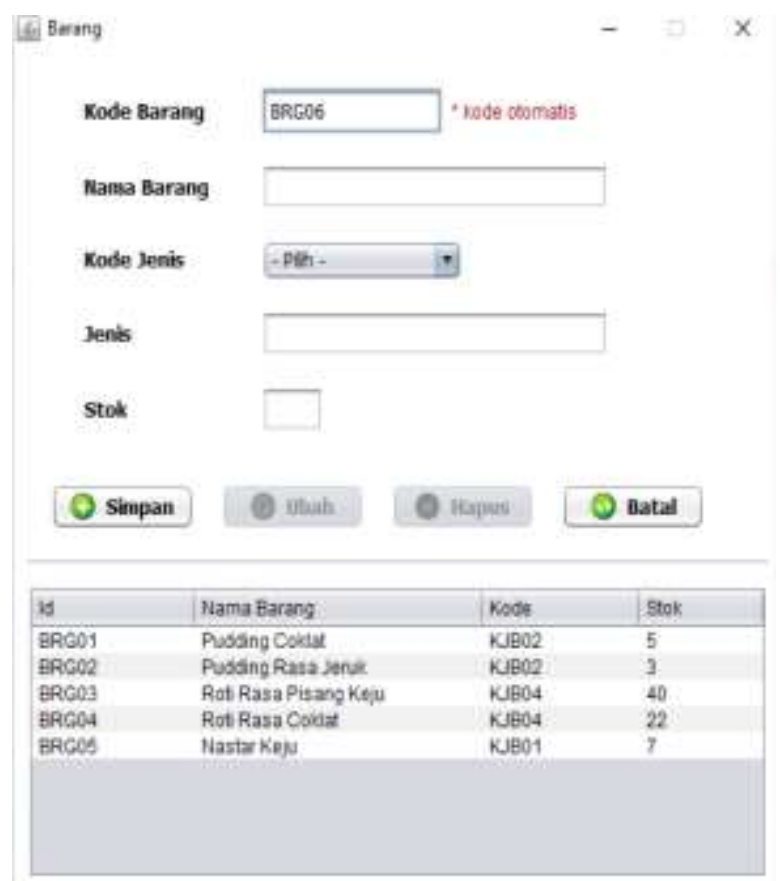

Gambar 4. Form Data Gudang

Layar di atas menampilkan tampilan form data gudang. Pada layar form data gudang untuk meng- input data gudang yang terdiri dari ID Bagian Gudang, Nama Bagian Gudang, Telp dan Alamat.

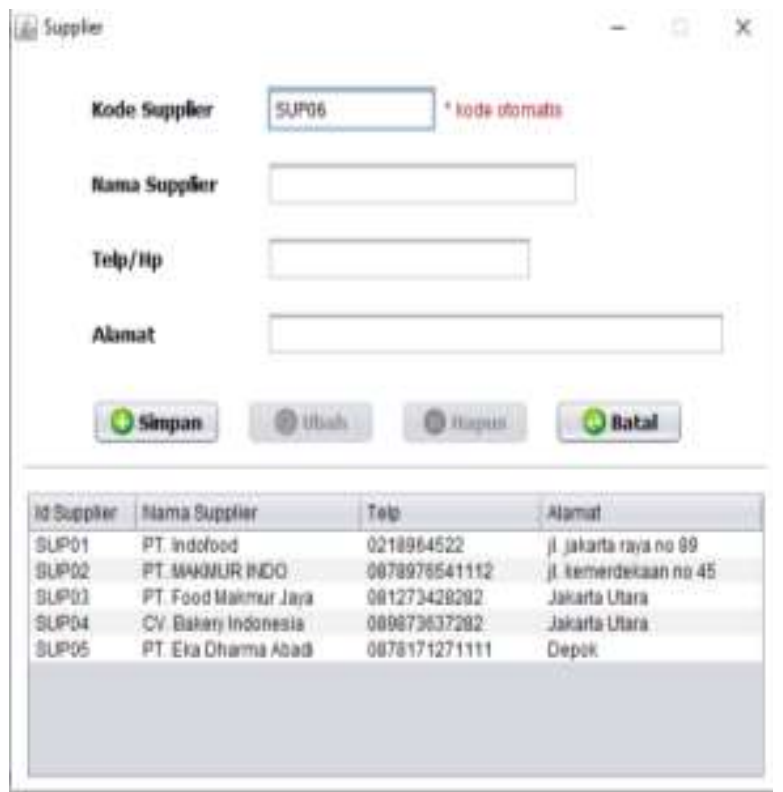

Gambar 5. Form Data Supplier

Layar di atas menampilkan tampilan form data supplier. Pada layar form data supplier untuk meng-input data supplier yang terdiri dari ID Supplier, Nama Supplier, Telp dan Alamat.

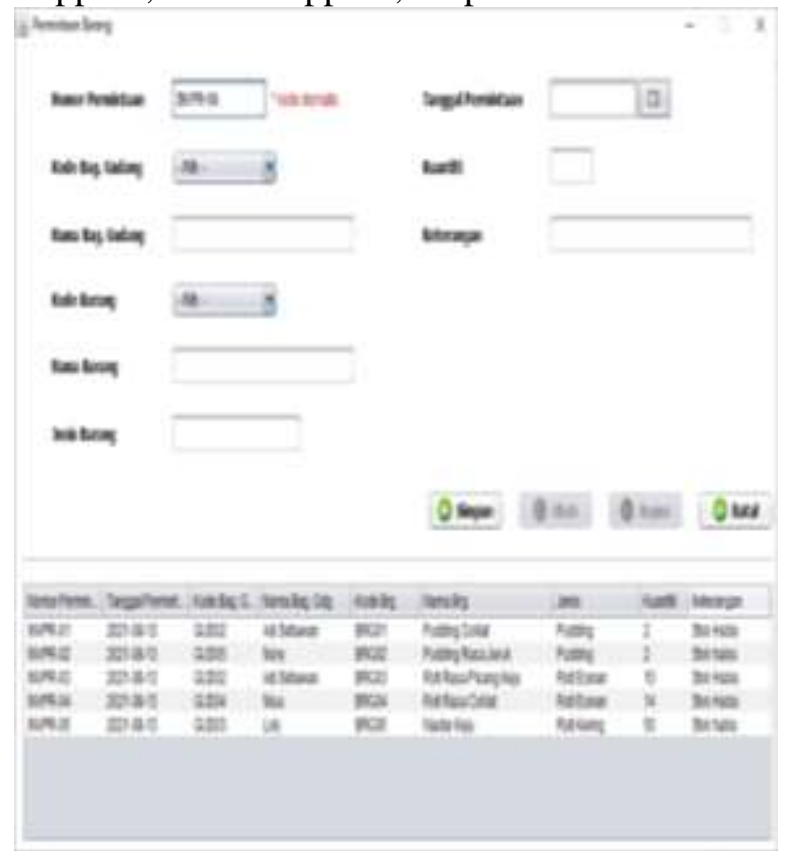

\section{Gambar 6. Data Form Data Permintaan Barang}

Layar di atas menampilkan tampilan form data permintaan barang. Pada layar form data permintaan barang untuk meng-input data 
permintaan yang terdiri dari No Permintaan, Tgl Permintaan, Kode Bagian Gudang, Nama Bagian Gudang, Kode Barang, Nama Barang, Jenis Barang, Kuantiti, Keterangan.

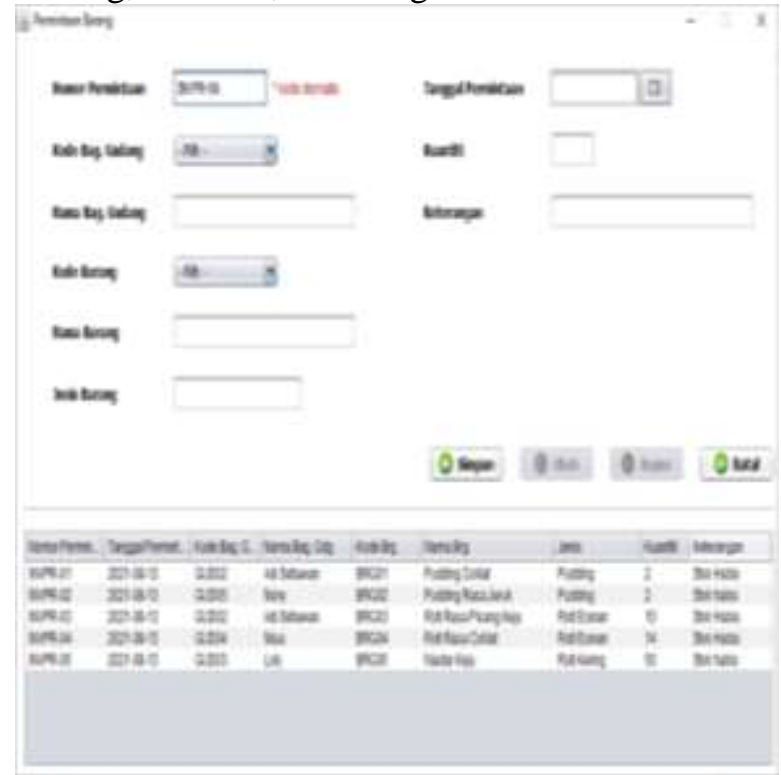

Gambar 6. Data Form Data Barang Masuk

Layar di atas menampilkan tampilan form data barang masuk. Pada layar form data barang masuk untuk meng-input data barang masuk yang terdiri dari Nomor Barang Masuk, Tgl Masuk, Kode Supplier, Nama Supplier, Kode Permintaan, Kode Barang, Nama Barang, Jenis Barang, Kuantiti dan Keterangan.

thengen

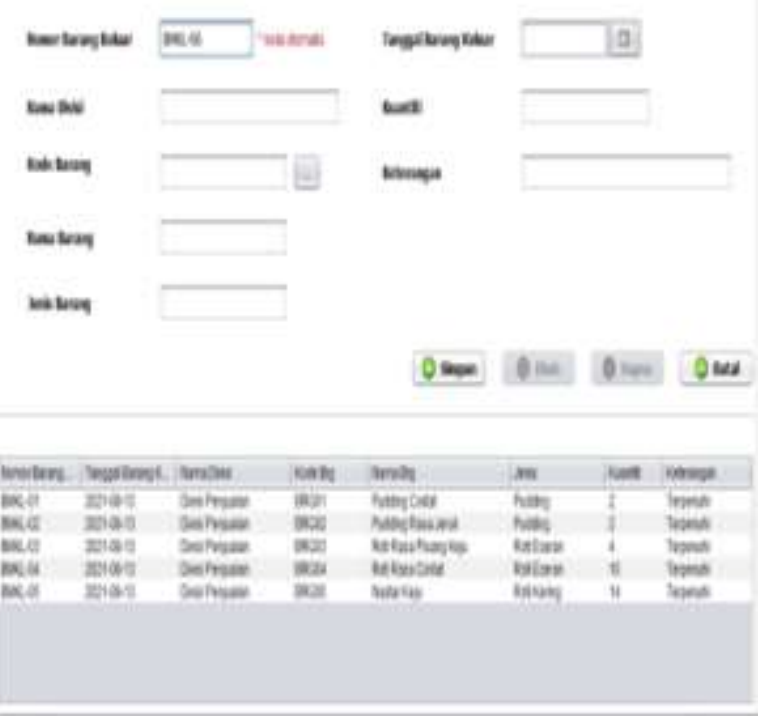

Gambar 6. Data Form Data Barang Keluar
Layar di atas menampilkan tampilan form data barang masuk. Pada layar form data barang masuk untuk meng-input data barang masuk yang terdiri dari Nomor Barang Keluar, Tgl Barang Keluar, Nama Divisi, Kode Barang, Nama Barang, Jenis Barang, Kuantiti dan Keterangan.

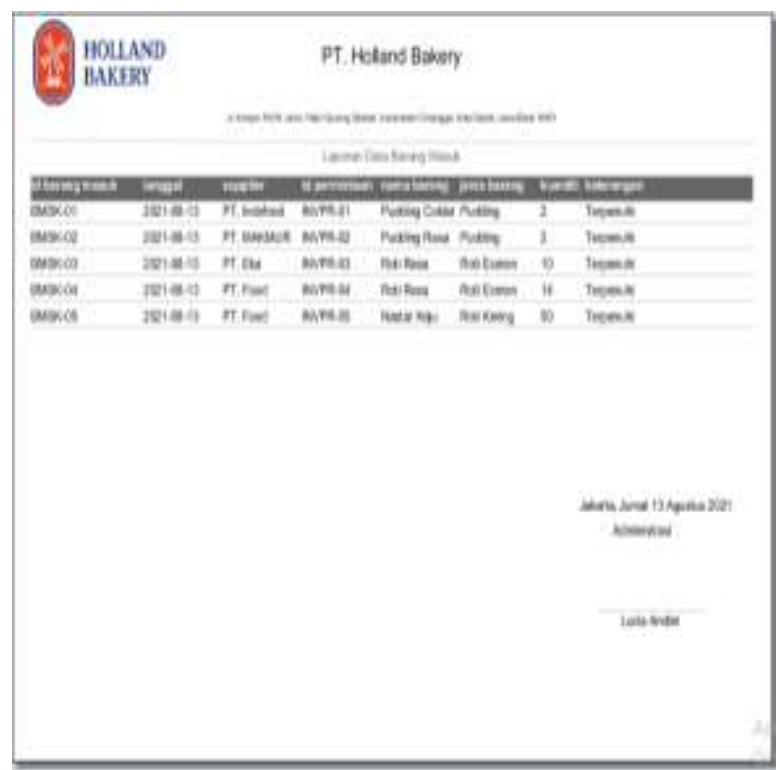

Gambar 7. Laporan Data Barang Masuk

Layar di atas menampilkan tampilan form laporan data barang masuk. Pada layar form data barang masuk digunakan untuk mengecek laporan data barang masuk terdiri ID Barang Masuk, Tgl Barang Masuk, Nama Supplier, ID Permintaan, Nama Barang, Jenis Barang, Kuantiti, dan Keterangan.

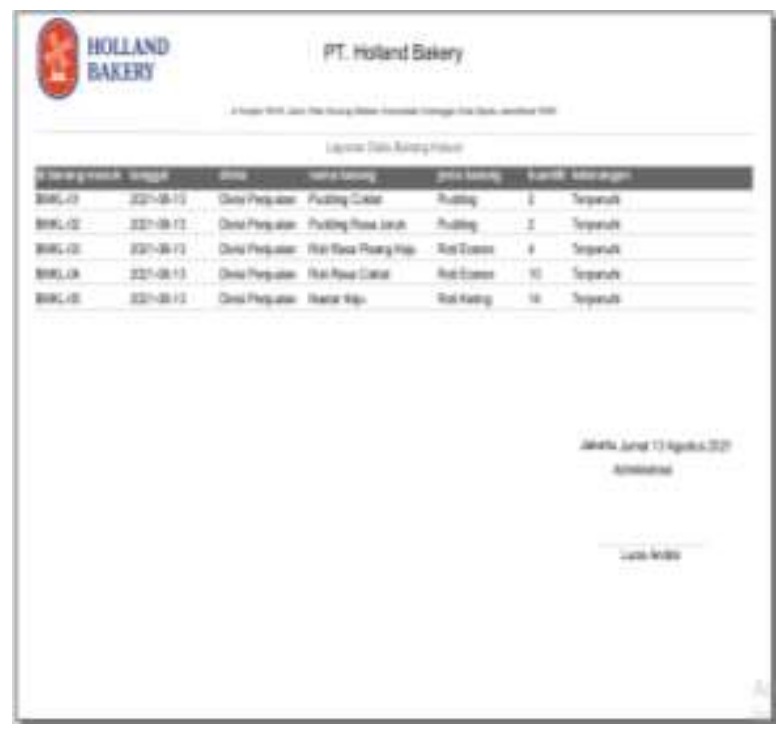

Gambar 8. Laporan Data Barang Keluar 
Layar di atas menampilkan tampilan form laporan data barang keluar. Pada layar form data barang keluar digunakan untuk mengecek laporan data barang keluar terdiri ID Barang Keluar, Tgl Barang Keluar, Nama Divisi, Nama Barang, Jenis Barang, Kuantiti, dan Keterangan.

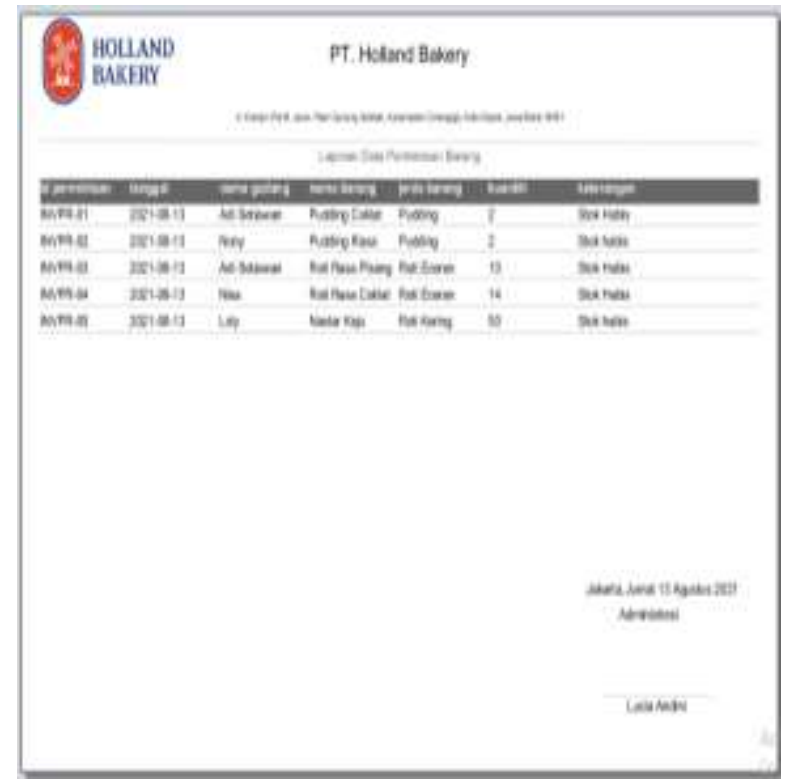

Gambar 9. Laporan Data Permintaan Barang

Layar di atas menampilkan tampilan form laporan data permintaan barang. Pada layar form data permintaan digunakan untuk mengecek laporan data permintaan barang terdiri ID Permintaan, Tgl, Nama Bagian Gudang, Nama Barang, Jenis Barang, Kuantiti dan Keterangan.

\section{SIMPULAN DAN SARAN}

Sistem aplikasi gudang ini dapat mengetahui laporan data pemasukan dan pengeluaran barang secara cepat dan akurat dengan aplikasi berbasis desktop. Sistem aplikasi gudang ini dapat memudahkan bagian gudang dalam melakukan pekerjaannya saat pembuatan laporan bulanan.

Penulis menyarankan interface lebih disempurnakan lagi untuk penambahan tool-tool dalam program dan dalam penggunaan sistem komputerisasi ini diharapkan selalu melakukan Back-Up Data, sehingga meminimalkan kemungkinan terjadinya kehilangan data-data apabila terjadi kerusakan pada Hardware ataupun Software pendukung.

\section{DAFTAR PUSTAKA}

Agusvianto, H. (2017). Sistem Informasi Inventori Gudang Untuk Mengontrol Persediaan Barang Pada Gudang Studi Kasus : PT.Alaisys Sidoarjo. Journal of Information Engineering and Educational Technology. https://doi.org/10.26740/jieet.v1n1.p40-46

Meisak, D. (2017). Analisis Dan Perancangan Sistem Informasi Persediaan Barang Menggunakan Metode FIFO Pada PT.Shukaku Jambi. Mediasisfo, 11(2), 862875.

Prasojo, M. (2011). Pengantar Sistem Informasi Manajemen . bandung: CV. Remadja Karya.

Putra, N. (2011). Research and Development, Penelitian dan Pengembangan: Suatu Pengantar. Jakarta: PT Raja Grafindo Persada.

Satzinger, J. W., Jackson, R. B., Burd, S. D. (n.d.). System Analysis and Design in A Changing World. USA: Cengage Learning.

Sugiyono. (2016). Metode Penelitian Kuantitatif, Kualitatif dan $R \& D$. Bandung: PT Alfabet.

Sutabri, T. (2012). Analisis Sistem Informasi. Yogyakarta: Andi.

Tyoso, J. S. P. (2016). Sistem Informasi Manajemen. Yogyakarta: DeePublish.

Waluyo, edy tekat bronto, Hanafri, M. I., \& Sulaeman. (2019). Perancangan Sistem Informasi Persediaan Barang Pada Gudang Sparepart. Sisfotek Global, 9(1), 13-19.

Wibowo, G. I., Rumagit, A. M., \& Tuturoong, N. J. (2014). Perancangan Aplikasi Gudang Pada Pt. Pakan Ternak Sejati. Jurnal Teknik Elektro Dan Komputer, 3(4), 11-18. 